\title{
Relationship Of LILA And IMT With The Incidence Of Anemia In Pregnant Women At Sungai Bilu Public Health Center Banjarmasin
}

\author{
Winda Ayu $\mathrm{F}^{* 1}$ \\ 1 SAINT Paul University Phillipines \\ Winda_ayu@gmail.com
}

Fitri Yuliana ${ }^{2}$

${ }^{2}$ Sari Mulia School Of Health Siecene

Fitri_yuliana@stikessarimulia.ac.id

Agnes Christie Rinda ${ }^{2}$

${ }^{2}$ Sari Mulia School Of Health Siecene

Agnes_christie_rinda@stikessarimulia.ac.id

\begin{abstract}
Objective: To analyze the relationship between LILA and BMI with the incidence of anemia in pregnant women at Bilu Banjarmasin River Health Center.

Method: This research uses quantitative analysis method with Chi-Square statistical test and Crosssectional design. The population in this study were all pregnant women in Bilu Banjarmasin River Health Center as many as 231 people with a sample size of 40 people. Sampling technique using Purposive sampling.

Results: The results showed that most cases of anemia occurred in pregnant women with abnormal LILA as many as 14 people $(73.68 \%)$ and in pregnant women with normal BMI of 11 people $(34.4 \%)$. Based on the result of Chi-Square statistic test, there is a relationship between LILA and the incidence of anemia in pregnant women $(p=0,002)$ and Fisher's Exact Tostada test relation between BMI with the incidence of anemia in the pregnant mother $(p=0,014)$.

Conclusion: There is a relationship between LILA and IMT with the incidence of anemia in pregnant women at Bilu Banjarmasin River Health Center.
\end{abstract}

Keywords: Anemia, LILA, IMT, Pregnant Woman

\section{INTRODUCTION}

Anemia in pregnancy is a condition of a mother with $\mathrm{Hb}$ content below $11 \mathrm{gr} \%$ in trimester I and III or less than $10,5 \mathrm{gr} \%$ in trimester II. Limit values are different from the condition of non-pregnant women due to the hemodialysis especially in the second trimester [1].
There are several indicators used to measure maternal health status in a region, one of which is maternal mortality (MMR). $\mathrm{AKI}$ is one of the indicators that are sensitive to the quality and accessibility of health service facilities. Based on Indonesia Demographic and Health Survey (SDKI) in 2012, AKI (related to pregnancy, childbirth, 
and childbirth) amounted to 359 per 100,000 live births. This figure is still quite high when compared with neighboring countries in the ASEAN Region. In 2007, when AKI in Indonesia reached 228, AKI in Singapore was only 6 per 100,000 live births, Brunei 33 per 100,000 live births, Philippines 112 per 100,000 live births, and Malaysia and Vietnam both reached 160 per 100,000 live births [2].

The main causes of maternal mortality were bleeding (28\%), eclampsia (13\%), unsafe abortion (11\%) and sepsis (10\%). The indirect cause of maternal death is Chronic Energy Deficiency (KEK) in pregnancy (37\%) and anemia in pregnancy (40\%). Antepartum and postpartum bleeding is more common in women who are anemic and more often fatal because anemic women cannot tolerate blood loss [3].

Pregnant women with KEK are mothers whose size is $<23.5 \mathrm{~cm}$ and with one or more of the following criteria: Pregnant mother's weight $<42 \mathrm{~kg}$, mother's height $<145 \mathrm{~cm}$, maternal weight in third trimester pregnancy $<45 \mathrm{~kg}$, body mass index (BMI) before pregnancy $<17.00$, and mother suffering from anemia $(\mathrm{Hb}<11 \mathrm{gr} \%)$ [4].

The Body Mass Index (IMT) is a simple tool to monitor the nutritional status of adults especially those related to deficiency and overweight, so maintaining a normal weight allows one to reach a longer life expectancy. Weight is seen from Quatelet or body mass Index (IMT) [5].
Pregnant women with below normal weight are often associated with pregnancy abnormalities, as well as low birth weight, whereas excessive weight increases risk or difficulties in labor. Body mass index (BMI) is a mathematical formula related to adult body fat [6].

Measurement of upper arm circumference (LILA) in pregnant women associated with Chronic Energy Deficiency (KEK). SEZ is a problem that often occurs in pregnant women. LILA less than $23.5 \mathrm{~cm}$ should be treated to avoid complications in the fetus. Less nutrition in pregnant women needs to get treatment so that no complications occur in mothers such as anemia, bleeding and maternal weight does not increase normally and infected with infectious diseases. Mothers experiencing KEK will be more at risk of giving birth to LBW. Another problem that often occurs during pregnancy is a decrease in hemoglobin levels due to an increase in plasma volume more than the volume of red blood cells. This decrease occurs at 8-32 weeks gestation .

Nationwide coverage of pregnant women gets Fe tablet 2014 by $85.1 \%$, the data has not reached the target program in 2014 by 95\%. The provinces in Indonesia in 2014 with the highest Fe coverage were in Bali Province (95\%), DKI Jakarta (94.8\%), and Central Java $(92.5 \%)$, while the lowest coverage was in West Papua Province (38.3\%), Papua (49.1\%), and Banten (61.4\%). The coverage of Fe tablets in South Kalimantan province 
was $79.8 \%$, still below the national average coverage [2].

According to the South Kalimantan Provincial Health Profile, Maternal Mortality Rate in South Kalimantan Province in 2007 was still high at $307 /$ 100,000 live births and infant mortality rate in 2007 was 39/1000 live births (SDKI data, 2007). The number of maternal deaths that occurred from 2007 to 2010 shows that the number of maternal deaths in South Kalimantan Province continues to increase from year to year. Of the number of maternal deaths in South Kalimantan, the percentage of deaths are $35 \%$ bleeding, Eklamsia 28\%, infection $12 \%$ and other causes $25 \%$ [7].

Data obtained from the Health Office of Banjarmasin City shows that the number of pregnant women suffering from anemia in January-December 2015 from 26 Puskesmas in Banjarmasin city is the highest in Puskesmas Sungai Bilu which is 46 people $(18,85 \%)$. Based on preliminary study data at puskesmas Sungai Bilu, it is known that the number of pregnant women with anemia in 2015 increased as much as 46 people (18.85\%) compared to 2014 that is as many as 28 people $(13.46 \%)$. In addition, when conducted data collection at Puskesmas Sungai Bilu, researchers also found some pregnant women who do Antenatal Care (ANC) has a size of the upper arm circumference of less than $23.5 \mathrm{~cm}$. The situation is certainly very unsafe for pregnant women and the fetus.
Based on data from my preliminary study at Bilu Banjarmasin River Health Center in August 2016, we found that 10 pregnant women who had pregnancy examination and $\mathrm{Hb}$ examination 4 pregnant women had the chronic energy (KEK) and had abnormal BMI but pregnant women are not anemic. According to the theory of SEZ and IMT that is not normal in pregnant women can cause anemia, so there is a gap between the theory and events in the field.

\section{METHODS}

This research uses quantitative analysis method with Chi-Square statistical test and Cross-sectional design.

The population in this study is all pregnant women in Bilu Banjarmasin River Community Health Center January to December Year 2016 as many as 231 people.

The sample in this study was taken from a portion of the population that is considered to represent the entire population. Sampling method in this research is Purposive sampling where sampling took for a certain purpose that pregnant women who checked $\mathrm{Hb}$ in June until July 2017. The sample in this research is a mother who does pregnancy examination and examination of $\mathrm{Hb}$ at Puskesmas Sungai Bilu Banjarmasin in June until July 2017 with a minimum number of 40 people. 


\section{RESULTS}

The results of research conducted on 40 respondents of mothers who conducted pregnancy examination and $\mathrm{Hb}$ examination at the Puskesmas Sungai Bilu Banjarmasin in June to July 2017 showed the results of the general overview of respondents as follows:

Table 1 Distribution of Frequency of Respondents by Age in the Public Health Center of Sungai Bilu Banjarmasin

\begin{tabular}{llll}
\hline & Age & Frequency & Percentage (\%) \\
\hline 1 & $<20$ years & 4 & $10 \%$ \\
2 & $20-35$ years & 36 & $90 \%$ \\
3 & $>35$ years & 0 & $0 \%$ \\
\hline & Total & 40 & $100 \%$ \\
\hline
\end{tabular}

Source: Primary Data

The table above shows that most pregnant women are pregnant women aged 20-35 years as many as 36 pregnant women (90\%).

Table 2 Distribution of Frequency of Respondents by Occupation

\begin{tabular}{llll}
\hline No & Jobs & Frequency & Percentage (\%) \\
\hline 1 & Civil servants & 2 & $5 \%$ \\
2 & Private Company & 5 & $12,5 \%$ \\
3 & Entrepreneurs & 10 & $25 \%$ \\
4 & Ousewives & 23 & $57,5 \%$ \\
\hline & Total & 40 & $100 \%$
\end{tabular}

Source: Primary Data

The table above shows most pregnant women are pregnant women who work as housewives as many as 23 pregnant women $(57.5 \%)$.

Table 3 Distribution of Frequency of Respondents by Parity

\begin{tabular}{llll}
\hline No & Parity & Frequency & Percentage (\%) \\
\hline 1 & Nulipara & 11 & $27,5 \%$ \\
2 & Primipara & 17 & $42,5 \%$ \\
3 & Multipara & 12 & $30 \%$ \\
4 & Grandemultipara & 0 & $0 \%$ \\
\hline & Total & 40 & 100
\end{tabular}

Source: Primary Data

The number of results showed that most pregnant women are pregnant women who have primipara parity as many as 17 pregnant women $(42.5 \%)$.

Table 4 Distribution of frequency of respondents by age of pregnancy

\begin{tabular}{llll}
\hline No & Age of pregnancy & Frequency & Percentage (\%) \\
\hline 1 & Trimester I & 11 & $27,5 \%$ \\
2 & Trimester II & 22 & $55 \%$ \\
3 & Trimester III & 7 & $17,5 \%$ \\
\hline & Total & 40 & 100
\end{tabular}

The table above shows that most pregnant women are pregnant women with gestational age entering the second-trimester category that is as much as 22 pregnant women (55\%)

Table 5. Distribution of upper arm circumference of pregnant women

\begin{tabular}{llll}
\hline No & LILA & Frequency & Percentage (\%) \\
\hline 1 & Normal & 21 & $52,5 \%$ \\
2 & Not normal & 19 & $47,5 \%$ \\
\hline & Total & 40 & 100 \\
\hline
\end{tabular}

Table 5 shows that the upper arm circumference of pregnant women is mostly pregnant women with normal upper arm circumference as many as 21 pregnant women $(52.5 \%)$

Table 6. Frequency distribution of body mass index of pregnant women at Bilu Banjarmasin River Health Center

\begin{tabular}{llll}
\hline No & IMT & Frequency & Percentage (\%) \\
\hline 1 & Normal & 32 & $80 \%$ \\
2 & Not normal & 8 & $20 \%$ \\
\hline & Total & 40 & 100 \\
\hline
\end{tabular}

It is seen that $80 \%$ of pregnant women have a normal BMI and $20 \%$ of pregnant women have an abnormal BMI.

Table 7. Distribution of frequency based on IMT classification at Bilu Banjarmasin River Health Center

\begin{tabular}{llll}
\hline No & IMT & Frequency & Percentage (\%) \\
\hline 1 & Low & 7 & $17,5 \%$ \\
2 & Normal & 32 & $80 \%$ \\
3 & Obesity & 1 & $2,5 \%$ \\
\hline & Total & 40 & 100 \\
\hline
\end{tabular}


It is seen that $80 \%$ of pregnant women have normal BMI, and only 1 pregnant woman has obesity IMT.

Table 8. Distribution of anemia frequency in pregnant women at Bilu Banjarmasin River Health Center

\begin{tabular}{llll}
\hline No & Anemia & Frequency & Percentage (\%) \\
\hline 1 & Anemia & 18 & $45 \%$ \\
2 & No anemia & 22 & $55 \%$ \\
\hline \multicolumn{2}{r}{ Total } & 40 & 100 \\
\hline & It was & seen that 22 & respondents
\end{tabular}

(55\%) were not anemic, and 18 respondents (45\%) were anemic.

Table 9. Distribution of the frequency of anemia classification in pregnant women at Bilu Banjarmasin River Health Center

\begin{tabular}{llll}
\hline No & $\begin{array}{l}\text { Anemic } \\
\text { clarification }\end{array}$ & Frequency & Percentage (\%) \\
\hline 1 & Not anemic & 22 & $55,5 \%$ \\
2 & Mild Anemia & 17 & $42,5 \%$ \\
3 & Moderate anemia & 1 & $2,5 \%$ \\
4 & Severe anemia & 0 & $0 \%$ \\
\hline & Total & 40 & 100 \\
\hline
\end{tabular}

It was seen that 22 respondents $(55 \%)$ did not have anemia, and 17 respondents (42.5\%) had mild anemia.

Table 10. LILA relationship with the incidence of anemia in pregnant women at Puskesmas Sungai Bilu Banjarmasin

\begin{tabular}{|c|c|c|c|c|c|c|}
\hline \multirow[t]{3}{*}{ LILA } & \multicolumn{4}{|c|}{ Anemic Cases } & & \\
\hline & \multicolumn{2}{|c|}{ Anemia } & \multicolumn{2}{|c|}{ Not anemic } & \multicolumn{2}{|c|}{ Total } \\
\hline & $\begin{array}{l}\text { Fre } \\
\text { que } \\
\text { ncy }\end{array}$ & $\%$ & $\begin{array}{l}\text { Freq } \\
\text { uenc } \\
\mathrm{y}\end{array}$ & $\%$ & $\begin{array}{l}\text { Fre } \\
\text { que } \\
\text { ncy }\end{array}$ & $\%$ \\
\hline Normal & 4 & $19.05 \%$ & 17 & $\begin{array}{l}80.95 \\
\%\end{array}$ & 21 & $100 \%$ \\
\hline $\begin{array}{l}\text { Not } \\
\text { normal }\end{array}$ & 14 & $73.68 \%$ & 5 & $\begin{array}{l}26.32 \\
\%\end{array}$ & 19 & $100 \%$ \\
\hline Total & 18 & $45 \%$ & 22 & $55 \%$ & 40 & $100 \%$ \\
\hline & & P Value & $\begin{array}{l}0,002 \\
0,05\end{array}$ & & & \\
\hline
\end{tabular}

The above table shows that the occurrence of anemia occurred in pregnant women with normal LILA as many as 4 people $(19.05 \%)$ and abnormal LILA as many as 14 people $(73.68 \%)$.
Chi-Square statistical test results show the results of the value of sig is 0.002 which means the value of $\operatorname{sig}<\alpha(5 \%)$ so that 0.002 $<0.05$ which means Ho rejected and $\mathrm{Ha}$ received. Based on these results can be concluded that there is a relationship between LILA with the incidence of anemia in pregnant women at the Puskesmas Sungai Bilu Banjarmasin.

Table 11. IMT relationship with the incidence of anemia in pregnant women at Bilu Banjarmasin River Health Center

\begin{tabular}{|c|c|c|c|c|c|c|}
\hline \multirow[t]{3}{*}{ IMT } & \multicolumn{4}{|c|}{ Anemia cases } & & \\
\hline & \multicolumn{2}{|c|}{ Anemia } & \multicolumn{2}{|c|}{ Not Anemic } & \multicolumn{2}{|c|}{ Total } \\
\hline & $\begin{array}{l}\text { Fre } \\
\text { que } \\
\text { ncy }\end{array}$ & $\%$ & $\begin{array}{l}\text { Freque } \\
\text { ncy }\end{array}$ & $\%$ & $\begin{array}{l}\text { Fre } \\
\text { que } \\
\text { ncy }\end{array}$ & $\%$ \\
\hline Normal & 11 & $34,4 \%$ & 17 & $\begin{array}{l}65,6 \\
\%\end{array}$ & 21 & $100 \%$ \\
\hline $\begin{array}{l}\text { Not } \\
\text { normal }\end{array}$ & 7 & $87,5 \%$ & 5 & $\begin{array}{l}12,5 \\
\%\end{array}$ & 19 & $100 \%$ \\
\hline Total & 18 & $45 \%$ & 22 & $\begin{array}{l}55 \\
\%\end{array}$ & 40 & $100 \%$ \\
\hline & & P Valı & $\begin{array}{l}0,014 \\
<0,05\end{array}$ & & & \\
\hline
\end{tabular}

The above table shows that the occurrence of anemia occurs in pregnant women with normal BMI of 11 people (34.4\%) and abnormal BMI of 7 people $(87.5 \%)$.

The result of Fisher's Exact Test statistic test shows the result of sig value is 0,014 which means sig value $<\alpha(5 \%)$ so that $0,014<0,05$ meaning $\mathrm{Ho}$ is rejected and $\mathrm{Ha}$ accepted. From these results can be concluded that there is a relationship between IMT with the incidence of anemia in pregnant women at the Puskesmas Sungai Bilu Banjarmasin. 


\section{DISCUSSION}

a. Correlation between LILA and anemia cases of pregnant women

The result of Chi-Square statistic test about the relationship of LILA with the occurrence of anemia in the pregnant mother showed the result of sig value equal to 0,002 which mean sig value $<\alpha(5 \%)$ so that $(0,002$ $<0,05)$ so $\mathrm{Ho}$ is rejected and $\mathrm{Ha}$ received. Based on these results can be concluded that there is a relationship between LILA with the incidence of anemia in pregnant women at the Puskesmas Sungai Bilu Banjarmasin.

The results of this study are also in line with the theory that pregnant women with malnutrition status or LILA less than $23.5 \mathrm{~cm}$ of mothers at risk of anemia, compared to mothers with good nutritional status or LILA more than $23.5 \mathrm{~cm}$ [9]. LILA is one way to know the nutritional status of pregnant women. If this size is low or small indicates less nutritional state due to lack of energy and protein suffered at the time of measurement done. The LILA measurement is intended to determine if a person has Chronic Energy Loss. Chronic Energy Deficiency (SEZ) is a condition where pregnant women experience malnutrition (calories and protein) that lasts long or chronic. Pregnant women with nutritional status are less at risk of experiencing KEK resulting in lack of nutrient intake so that the formation of hemoglobin disrupted, while pregnant but also experienced blood dilution because of the process of pregnancy so that there was anemia [1].

The results of this study are in line with research conducted by Marlapan, Sandrayayuk et al. entitled "The Relationship of Nutritional Status With Anemia Occurrence In Pregnant Women In The Work Area of Tuminting Community Health Center of Tuminting Sub-district of Manado City". In this study, the nutritional status was measured by LILA and obtained p-value value $0.005<0.05$ so it concluded there is a relationship of nutritional status with the incidence of anemia in pregnant women in the work area of Tuminting Health Center Tuminting District Manado.

b. Correlation of IMT and anemia cases

The result of Fisher's Exact Test statistic on the relationship of BMI with the incidence of anemia in pregnant women shows the result of sig value is 0,014 which means sig value $<\alpha(5 \%)$ so that $0,014<0,05$ meaning $\mathrm{Ho}$ is rejected and $\mathrm{Ha}$ accepted. Based on these results can be concluded that there is a relationship between IMT with the incidence of anemia in pregnant women at the Puskesmas Sungai Bilu Banjarmasin. The results of this study are in line with the theory that the IMT is not normal can cause anemia due to lack of nutrient intake in pregnant women. However, in this study also a normal BMI is more anemic, so there are other possible factors that also affect anemia even though the pregnant women have 
normal BMI. Non-adherence of pregnant women consuming $\mathrm{Fe}$ tablets and the lack of knowledge about the importance of iron tablets during pregnancy is one of the factors that can cause anemia. Parity is the number of babies born to a mother, either giving birth who are still alive or stillborn. The risk of a mother having anemia in pregnancy is one of the causes is the mother who often gave birth and in the next pregnancy, the mother is less attention to good nutrition in pregnancy. This is because during pregnancy nutrients will be divided for the mother and for the fetus. The tendency that the more the number of births (parity), the higher the incidence of anemia. Knowledge of pregnant women is very influential on the nutrient of babies contained and also the consumption pattern of foods containing iron, because if iron deficiency during pregnancy in a relatively long time will cause anemia [9].

Another factor that becomes the SEZ parameter other than LILA is BMI which is measured from the ratio between weight and height. If $\mathrm{BMI}$ is less then a person is at risk of experiencing KEK. SEZ is one sign of a person experiencing malnutrition. Inadequate nutrition intake in pregnant women will result in the formation of hemoglobin is impaired so that the risk of anemia [1]. The results of this study are in line with research conducted by Utami [10] entitled "The Relationship of Nutritional Status With Anemia Occurrence In Pregnancy In Pregnant Poly RSUD Dr. Soegiri Lamongan ". In this study, the nutritional status was measured by BMI and obtained p-value value $0.006<0.05$ so it concluded there was a relationship between nutritional status with the incidence of anemia in pregnancy.

\section{REFERENCES}

[1] Saifuddin, Abdul Bari, dkk. 2010. Pelayanan Keehatan Maternal dan Neonatal. Jakarta: Yayasan Bina Pustaka.

[2] Dinas Kesehatan Kota Banjarmasin. 2015. Laporan Tahunan. Banjarmasin: Dinkes Kota Banjarmasin.

[3] Wiknjosastro, Hanifa. 2011. Ilmu Kebidanan. Jakarta: Yayasan Bina Pustaka Sarwono Prawirohardjo.

[4] Kristiyanasari, Weni. 2010. Gizi Ibu Hamil. Yogyakarta: Nuha Medika.

[5] Suparyanto. 2011. Kekurangan Energi Kronis (KEK) pada Ibu Hamil. Jakarta: Salemba Medika.

[6] Arisman. 2009. Gizi Dalam Daur Kehidupan. Yogyakarta: Nuha Medika.

[7] Dinas Kesehatan Provinsi Kal-Sel. 2010. Profil Dinas Kesehatan Kal-Sel Tahun 2007-2010. Dinkes Provinsi Kal-Sel.

[8] Supariasa, I.D.N., Bakrie, B., Fajar. 2009. Penilaian Status Gizi. Jakarta: EGC.

[9] Notoatmodjo, S. 2010. Metodologi Penelitian Kesehatan. Jakarta: Rineka Cipta.

[10] Utami, Devi dkk. 2010. Hubungan Status Gizi Dengan Kejadian Anemia Pada Ke hamilan Di Poli Hamil RSD $d r$. Soegiri Lamongan. Jurnal Surya. 